\title{
Fragments of Europeanization of Georgian Property Law and Law of Obligations in the Context of Reception of German Law
}

\author{
Tamar Zarandia \\ Natia Chitashvili \\ Faculty of Law, \\ Ivane Javakhishvili Tbilisi State University \\ Chavchavadze Ave. 3 , \\ Tbilisi 0179, Georgia \\ E-mail: tamar.zarandia@tsu.ge \\ E-mail: natia.chitashvili@tsu.ge
}

Abstract: The present research article focuses on the description of the dynamics of Europeanization of two fundamental concepts of Georgian property law and the law of obligations - acquisition of a thing from a non-authorized alienator and the unified concept of breach of obligation-in the context of reception of German law. At the historical stage of formation of the Civil Code of Georgia (CCG), focusing on the conceptual framework of German civil law, the German law, in its turn, was an integral part of the Europeanization process. Hence, Europeanization influenced the development of Georgian civil law through the reception of German law. When referring to the reception of German law in this article we simultaneously mean the process of Europeanization of Georgian civil law, which penetrated not directly but rather through the reception of European (in this case, German) codification. The ongoing reform of Georgian civil law inevitably requires its legal harmonization with EU codifications in the context of central paradigms of acquisition of a thing from a non-authorized alienator and the unified concept of breach of obligation. Analysis of the dynamics and often contradictory root of the Europeanization of Georgian private law will enable scholars and legislators conduct legal approximation process on the basis of research-based recommendations.

Keywords: acquisition of property from a non-authorized person, breach of contract, contract law, Europeanization, property law, reception, uniform contract law 


\section{Europeanization of property law and law of obligations in the context of formation of uniform law}

Since the 1990s, the interest in preservation of legal identity between European legal systems has been overcome by the strive for the minimization of national regulatory differences (Mátyás, 2008, p. 63), the purpose of which was to free international transactions from national legal barriers and increased economic expenditures (Wagner, 2002, pp. 995-1023) and the formation of common "contractual infrastructure" for the EU market and economy (PECL, pp. xxixxii; Bueno Diaz, 2008, p. 5; Mátyás, 2008, p. 65). Different from contract relations and thus often controversial "domestic regulation was found to be the obstructing factor for not only interstate trade, but also for fair competition" (DiMatteo et al., 2013, p. 505). Intensification of the efforts of the academic society (Keirse, 2011, pp. 39-42; Mátyás, 2008, pp. 66-68) and state policies to move from legal approximation to full unification was triggered by the recognition of state-political importance of Europeanization, a provision (Letto-Vanamo \& Smits, 2012, p. 2; Lando, 1974, pp. 6-7) for legal certainty (Hesselink, 2010, p. 8) and prevention of risks (Paul, 1999, p. 2), and the need to create a free trade area (Mátyás, 2008, p. 64; Lando, 2008, pp. 59-69). In the modern world, law also crosses the state borders, and together with trade and legal systems, responds to international processes through the development of model laws and ratification of conventions (Zeller, 2007, p. 1).

In the light of the historical dynamics of formation of national and unified socalled 'soft-law' codifications of civil law, the contract law can be recognized as the favorite of the Europeanization process (Basedow, 2005, p. 487). When discussing the Europeanization of German and Georgian law, multiple content is embodied in the term 'Europeanization' (Miller, 2011, pp. 4-14; Twigg-Flesner, 2013; Rosett, 1992, pp. 687-688). Europeanization of contract law is shaped by the adoption of directives with particular aspects of contract law by the EU (Joerges, 2005, pp. 63-84). Here the focus has been predominantly on aspects of consumer contract law, rather than general contract law, or even law specifically relating to business-to-business transactions (Twigg-Flesner, 2013, p. 10). This article focuses on the basic direction, revealed through the development of creeping codifications (Berger, 2001, p. 21; 2010) of the so-called 'soft law' (Chanturia et al., 2001, p. 1). Thus, when we speak about the Europeanization of German, and consequently, Georgian civil law, we mean its approximation with legal concepts, generalized by the instruments of unified law, which, for example, became most general internationally recognized contract principles in the field of contract law (Ciematniece, 2010, p. 31; Brunner, 2009, p. 39). Hence, 
the impact of Europeanization in the format of unified law has considerably changed the landscape of contract law in the legal order of the EU countries and has conditioned its transformation.

On 1 July 2016, the EU-Georgia Association Agreement ${ }^{1}$ entered into force and Georgia's undertaking to approximate its legal framework with that of the EU in the field of private law necessitated comprehensive conceptualization of new realities for efficient and enhanced administration of the EU integration process. The foregoing means promotion of the scrutiny of legal approximation with the EU institutions regulating civil-law relations and harmonization of private law at normative level, further improvement of legislative methodology that is based on the study of the EU law, research and sharing of international experience in the field of implementation of the institutions of EU law in domestic legislation and harmonization with it. The Europeanization processes were not so active in property law as in the law of obligations (van Erp, 2012, p. 1), which was conditioned by essential differences between the legal systems of the EU Member States. Owing to the essential differences between the property law systems, no uniform instruments like UNIDROIT Principles of International Commercial Contracts (UNIDROIT, 2014), Principles of European Contract Law (PECL, Parts I, II-Rev. 1998, Part III-2002; Lando \& Beale, 2000), United Nations Convention on Contracts for the International Sale of Goods (UN, 2010), or Draft Common Frame of Reference (von Bar et al., 2009) were adopted in this field.

The scope of the Europeanization of Georgian civil law, through comparative, historical and teleological methodic research, can be analyzed in the context of reception of German law, which will be demonstrated on the example of two key institutes of property law and law of obligations: acquisition of a thing from a non-authorized alienator and unified concept of breach of obligation. Selected research topics as fundamental legal paradigms and institutes of property and contract law essentially determine legal nature and system characteristics of two major fields of national private law, impact the whole dichotomy of civil code and provide grounds for generalization of impediments to Europeanization.

1 The Association Agreement between the European Union and the European Atomic Energy Community and their Member States, on the one side, and Georgia, on the other side, 27.06.14, date of publication 11.09.14, temporary application mode 01.09.14, date of full entry into force 01.04.16. 


\section{Characteristic features of German property law on the example of acquisition of a thing from a non-authorized alienator}

\subsection{General description of the institute of acquisition of a thing from an non-authorized alienator}

The question of acquisition of a thing from a non-authorized alienator is still pressing in modern jurisdictions and different countries have different solutions for this conflict of interests. In Georgian law, regulation of good-faith acquisition was oriented on the relevant rules of the German Civil Code (BGB); however, full reception of these rules was not accomplished. According to Article 187 of the CCG, a purchaser becomes an owner of a thing even if the alienator was not the owner of the thing concerned, but the purchaser is acting in good faith with this regard. It should be stressed that according to Georgian law good faith should be present before the transfer of a thing, however a transfer also includes the establishment of indirect possession (CCG, Art. 186 II), while German law requires the existence of good faith until the end of acquisition. ${ }^{2}$ This difference expands the options of good faith acquisition in Georgian law as compared with German one. It should be mentioned that both in Georgia and in Germany a purchaser is not regarded as a good faith one if he/she was aware or should have been aware (Bassenge, 2019, Rn. 10; Chechelashvili, 2006, p. 201) ${ }^{3}$ that the alienator was not the owner (CCG, Article 187 I/ BGB, §932, II). As per Article 187 of the CCG, good faith of a purchaser means that the purchaser believes that he/she is acquiring a thing from a real owner. Identity of the purchaser should be the standpoint in assessing good faith.

\subsection{Dispossession of a thing against will}

Good-faith acquisition is excluded if a thing was stolen, it was lost or the owner was otherwise dispossessed of it against his/her will. However, good-faith acquisition is possible in this situation if the case concerns money, securities and/or things that were alienated through a public auction (CCG, Art. 187 II). Georgian law excludes good-faith acquisition when transaction is gratuitous (CCG, Art. 187 II), which is explained by the disputable nature of gratuitous acquisition (Putkaradze, 2001, pp. 17-25; Kurzynsky-Singer \& Zarandia, 2014, p. 127). A thing is believed to be lost when direct possessor, who can be either

2 According to paragraphs 933 and 934 of the BGB, good faith is required before the actual transfer of a thing.

3 The wording "should have been aware" means that non-awareness of the fact is conditioned by gross negligence of the purchaser. 
an owner or an intermediate possessor, was dispossessed against his/her will. It is worth mentioning that Part II of Article 187 applies to cases when loss of a thing is conditioned by negligence of the owner, e.g., an individual has not duly locked the suitcase and his watch was lost from it. The same rule applies even when a thing is lost due to gross negligence (Westermann, 2012, p. 107). Hence, Article 187 protects an owner from loss of his/her possession status against his/ her will. It should as well be mentioned that the owner is also protected when the thing is lost by a holder thereof (CCG, Art. 155 II) as the holder acts in accordance with the directions of the owner of the thing (Kropholler, 2014, p. 716). It is worth mentioning that in German law, dispossession of a thing against the will of the owner excludes the option of good-faith acquisition.

\section{3 "Good-faith" acquisition of property right over a movable thing in Georgian judicial practice-a changed balance of interests}

According to the wording of Article 187 of the CCG, effective prior to amendments of 2000, dispossession of a thing against owner's will excluded good faith of a purchaser. The later amendment specified the wording and pursuant to current version of the Article a good faith purchaser cannot become the owner of a thing if the owner lost this thing, or it was stolen, or the owner was otherwise dispossessed of it against his will. Article 187 is rarely applied in Georgian judicial practice. This was conditioned by the Decision of the Supreme Court of Georgia (No. 3K-624-02) of 9 September 2002. In this case, the claimant entered into negotiations with the counterparty with a view to sale of a car and transferred his car and registration certificate to the latter on 8 October 2000 on the condition that the car would have been re-registered on behalf of the latter after the repayment of the sales price. With the help of a notary the counterparty forged the general power of attorney using transferred registration certificate for own benefit. He stated in the forged power or attorney that the claimant had transferred the right of disposal of the thing to him. The same day the counterparty pledged the car with the bank to secure 8,000 US dollars liability. In 2010 the claimant found his car on a car fair. The car was offered for sale by the bank for non-payment of the loan. The claimant claimed the return of the thing. In assessing this case, the court of law refused good faith of the purchaser because of the dispossession of the thing against the will of the owner. Whereas the purpose of transfer of the car to the counterparty was not the pledge of the thing, transfer of the car to the purchaser was qualified as a dispossession of the owner of the thing against his will.

It should be said that good-faith acquisition related rules reflect the balance of 
interests between the interests of an owner and sustainable civil circulation, found by the legislator. With Part II of Article 187 of the CCG, the legislator excludes good-faith acquisition when a thing was lost, stolen or the owner was otherwise dispossessed of it. The text of the law gives rise to an assumption, that 'will' does not mean a legally important declaration of will, which can be expressed through some conditions, by rather actual consent on the loss of direct ownership over a thing; hence, the purpose of the transfer of thing should not matter in such cases (Dzneladze, 2007, p. 82). In the case concerned, the claimant has personally transferred a thing to the counterparty, at his own free will. He has not lost direct ownership over the thing against his will, the thing was not stolen and the owner was not dispossessed of this thing against his well. In such cases, the law should give preference to the protection of the interests of the good-faith purchaser. Thus, the purpose of transfer of a thing should not play any role in the case of good-faith acquisition. Quite probably, the above decision of the Supreme Count of Georgia was criticized in Georgian doctrine due to this very reason (Chachava, 2004, pp. 760-782).

The said decision of the Supreme Court can be viewed from another standpoint as well. As already mentioned, despite similarity, the Georgian regulation of good-faith acquisition is simpler and more schematic. Many details of German law are absent in Georgian regulation. On the one hand, imposition of burden of proof of good faith on the purchaser complicates good-faith acquisition, which gives preference to owner's interests. On the other hand, the specificity of the Georgian regulation in certain aspects leads to the material expansion of the option of good-faith acquisition as compared with German law. First and foremost, this concerns the role of publicity principle with regard to acquisition of property right. In German law, the above-described mechanism of good-faith acquisition, when transfer is substituted by indirect possession, ensures certain protection against bad-faith behavior, which is absent in Georgian law. However, in contrast to the foregoing, if an owner is dispossessed of a thing against his/her will, the loss of property right by the latter is not justified (Wolf \& Wellenhofer, 2016, Rn. 30). According to Part II of Article 187, theft and loss of a thing are only some specific cases of the concept of loss of actual possession over a thing.

Taking the above-mentioned into consideration, it may be asserted that the Europeanization of Georgian property law started with the reception of German property law, which covered the basic structure of property law. Incomplete reception and different interpretations of the rules by the courts of law changed the balance of interests embodied in the German model. Likewise, the CCG demonstrates a paradigmatic conflict with German civil law and the European codifications in its regulation of certain institutes of the law of obligations, 
which speaks of the fragmentary nature of reception and inconsistent process of Europeanization.

\section{Analysis of the reception of German law on the example of breach of contract in the field of law of obligations}

\subsection{Importance of the concept of breach of obligation for the assessment of the scope of Europeanization}

Recourse to the concept of breach of obligation for the illustration of the fragmented process of Europeanization and reception is conditioned by its crucial importance and relevance for the protection of contractual, performance interest. Specifically, a breach of obligation results in non-exercise of one of supreme private law values - legitimate contractual interest in performance of obligation (initial content) - for a counterparty. In the context of legal protection, performance interest (Friedmann, 1995, p. 628), "potential contractual interest" (von Bar et al., 2009, p. 942; Kreitner, 2005, p. 23) is a particularly important value in any legal system (Chen-Wishart, Loke \& Ong, 2016; Rowan, 2012) moreover for "performance oriented" (Zoidze, 2005, pp. 299-304) civil law area (Friedmann, 1995, p. 628; Rowan, 2012, pp. 1-2). After the transformation of contract relationship into breach of obligation, the "compensation interest" (Rowan, 2012, p. 2) becomes the point of agenda. Specific types of breach of obligation give rise to the relevant right to specific performance, the availability of which is the manifestation of protection function of contract law. Insofar as the purpose of a contract is its performance (Williston \& Lord, 1990, p. 306), a uniform regulation of essentially connected thereto category-the concept of breach of obligation - becomes particularly important for any legal system.

\subsection{Modernization of the concept of breach of obligation in German civil law}

"After regaining her independence, the young Georgian state has repeatedly faced major legal reforms" (Burduli, 2018, p. 3; Troitiño \& Cochia, 2011, pp. 89-92; Chochia \& Popjanevski, 2016, pp. 197-208; Chochia, 2013, pp. 1-189). The process of Europeanization of Georgian civil law followed the path of reception of German law (Zarandia, 2007, pp. 294-304; Surguladze, 2002, cited in Zoidze, 2003, p. 90; Gegenava, 2013, p. 5). German law also had its impact on the formation of common law institutes (Riesenfeld, 1993, pp. 89, 95-96).

The CCG, adopted on 26 June 1997, was based on BGB in defining the conceptual 
essence of each law institution. Despite the foregoing, the reception of German law was often episodic and fragmentary, which is proved by a paradigmatic contradiction with German civil law and European codifications in regulation of specific institutions. Professor Burduli (2018) truly states that legal reforms and the whole process of reception of law in general should be the essential constituent of a single social system. If legal reforms do not result in the creation of a uniform legal system and conception, these reforms will be called "pseudo-reforms", necroreception, i.e. the dead-born process (Burduli, 2018, pp. 3-15).

Non-systematic, episodic nature of the reception of German law had its determinant factors on the backdrop of the fundamental reformation of German law of obligations. The CCG failed to systemically reflect the results of a fundamental reform of German law of obligations, accomplished in 2002 (Gesetz zur Modernisierung des Sculdrechts, Vom 26.11.2001), which was essentially based on CISG and draft UPICC, and in this light was itself a demonstration of the Europeanization of German law. The fundamental reform in German law resulted in the unification of the notion of breach of obligation and uniformity of secondary rights, remedies. Any type of non-performance of obligation was united in a single concept (Löwisch, 2003, p. 144) - breach of obligation (Pflichtverletzung), which covered four types of non-performance: (1) delay on the part of the debtor; (2) impossibility to perform obligation; (3) defective performance; and (4) breach of obligation to assistance in contract performance. The reform united all types of non-performance of obligation in a uniform concept of breach of obligation, which now already comprises all known and possible deviations from the contractual obligation regime (Markesinis, Unberath \& Johnston, 2006, p. 379). Following the fundamental reform, impediment to performance of obligation (Leistungsstörungen) is used with a synonymous meaning to the Breach of Contract, a category well familiar in the common law system. Breach of contract in German law is defined as full or partial failure to perform contractual obligations (Markesinis, Unberath \& Johnston, 2006, p. 387). Respectively, a presence of breach of contract is determined on the basis of an objective criterion - there is a breach in case the failure to fulfil contractual obligation as an objective fact is confirmed. 


\subsection{The impact of Europeanization on the formation of a unified concept of breach of obligation}

German law has aligned the modernization of the concept and types of breach of obligation, formation of the Universal Doctrine of Breach of Contact (Basedow, 2005, pp. 490ff) with model regulation of the so-called 'soft-law' (Chanturia et al., 2001, p. 1) creeping codifications of uniform legal instruments and in this way has expanded the scope of the Europeanization of national law within the state.

The new regulatory-conceptual approach to the concept of breach of obligation

has met worldwide acceptance. Its most concise expression is perhaps Article 7.1.1 of the UNIDROIT-Principles, which defines non-performance as the "failure by a party to perform any of its obligations under the contract, including defective performance or late performance." Similar language can be found in Article 8:101 of the European Principles. (Basedow, 2005, p. 491)

According to PECL, which recognizes the uniform concept of breach of obligation, 'non-performance' denotes any failure to perform an obligation under the contract, whether or not excused, and includes delayed performance, defective performance and failure to co-operate in order to give full effect to the contract (PECL, Art. 1.301 (4)).

A similar approach is found in CISG:

The seller's breach of contract is defined, by Article 45 CISG, as the failure "to perform any of his obligations under the contract or this Convention." As a matter of principle the Convention is based upon a uniform concept of breach of contract which includes all kinds of non-compliance such as non-delivery, late delivery, delivery of goods of a wrong description, lack of conformity of the goods, etc. The remedies laid down in the Convention are basically the same for all the different types of breach. (Basedow, 2005, pp. 490ff)

The 'soft-law' codifications, as a general rule, provide for compromised generalization of the approaches of legal systems. In the case concerned as well, through provision for the unification of the concept of breach of obligation, the uniform instruments aligned this concept with conceptual essence of common law countries. 
The comprehensive and homogeneous concept of breach laid down in Article 45 CISG reflects a long tradition of the common law while it introduces the new category of non-conformity into civil law jurisdictions [...] it breaks a long tradition in many civil law countries [...] These observations may be interpreted as a rapprochement of traditional civil law countries to the common law. However, what has finally convinced national legislators was rather the international model of CISG and the UNIDROIT-Principles. (Basedow, 2005, pp. 490-491)

\subsection{Non-systemic reception of fundamental reform by Georgian law}

Although Georgian law has recognized the principle of faulty liability, it still maintained the pre-reform fragmentary regulation, provided by German law, for the regulation of types of breach of obligations. The foregoing is evidenced by the fact that there is no uniform concept of breach of obligation in Georgian legal space. On the one hand, Georgian law acknowledged the principle of responsibility based on fault, whilst with regard to regulation of particular type of breach of contract, as GCC maintained, preserved the pre-reform fragmented regulatory model of German law. The CCG does not provide for exhaustive regulation of different types of breach. For instance, stipulations regulating defective performance as one of the types of breach of obligation and related thereto the right to remedies (secondary claims ${ }^{4}$ ) are scattered amongst the provisions regulating specific types of contracts ${ }^{5}$ (private part of law of obligations) and are not concentrated in the General Part of Law of Obligations. ${ }^{6}$ In case of placement of provisions regulating defective performance in the general part of the law of obligations, these provisions would be equally applicable to a particular case of defective performance in the context of different types of contracts (sales, rent, etc.). From a systemic point of view, the range of remedies, associated with defective performance, is not concurrent with the system of remedies prescribed by the General Part of Obligations. Only the late performance (delayed performance) on the part of the debtor is regulated separately, and only one article of the Chapter, one normative provision regulating this issue, concerns the impossibility to perform. This normative provision regulating

4 Claims derived from breach of contract: price reduction, damages, specific performance, avoidance (repudiation/termination of contract).

5 Sections 459 and 462 of the BGB were also aware of a similar regulation until 2002, the change of this was one of the major conceptual achievements of German fundamental reform.

6 Except for Article 280 of the CCG regulating quality of performance of obligation from General Part of Law of Obligations. 
impossibility is marked with deficient regulation-impossibility is described not as an independent type of breach of obligation, but rather as a situation excluding late performance. In this context as well, the CCG is close to the pre-reform regulation of the $\mathrm{BGB}$, which provided for regulation of only two types of breach of obligation: late performance and impossibility to perform (Basedow, 2005, pp. 490ff). However, the CCG has considerably deviated even from BGB with respect to regulation of impossibility to perform, as BGB provided for exhaustive regulation of the types of impossibility to perform. The existence of breach of duty of care as one of the types of non-performance is not directly visible within the system of breach of obligation of Georgian civil law. Recognition of breach of duty of care as one of the types of non-performance can be established through the interpretation of CCG provisions (CCG, Art. 405 III(b) and 316 II), according to which avoidance of a contract is impossible in case of such breach of duty of care, which can not be regarded as a reasonable ground for termination of a contract. Here the concept of essential breach is more evident than the purpose to regulate breach of duty of care as a separate type of breach. However, in itself, the legal construction, which provides for the right to terminate, avoid the contract on the basis of breach of duty of care allows for the interpretation of the breach of duty of care as a separate type of breach. Such indirect regulation of duty of care is not the regulatory model of the uniform system of breach of obligations, set out in BGB, the model of which is also followed by soft-law codifications. However, the elements of breach of obligation, conceptual ground and relevance provided by the legislator for nonabidance to duty of care, in terms of the availability of the right to terminate (avoid) a contract, already creates a paradigmatic-dogmatic basis and a chain of historical dynamics for legislative reforms.

\section{Conclusion}

CCG demonstrates a paradigmatic conflict with German civil law and European codifications in its regulation of certain institutes of property law and law of obligations, what speaks of the fragmentary nature of the reception and inconsistent process of Europeanization.

In Georgian law, the regulation of good-faith acquisition has focused on relevant provisions of the German Civil Code. However, the reception of these provisions by Georgian law was incomplete. The reception of German property law in Georgia, first and foremost, covered the basic structures of regulation. The 
provisions, subject to transposition, were simplified. In some cases the details, that prima facie seem to be accessory, were left beyond the scope of reception, but deeper analysis clearly proves that the balance of interests, initially implied by the legislator, has changed, as it was the case with the acquisition of a thing from a non-authorized alienator. The foregoing is supplemented by interesting cases of judicial practice, which prove that the situation is quite different with regard to many issues.

The CCG adopted in 1997, before the end of fundamental reform (2002) of BGB law of obligations, reveals considerable dogmatic contradictions with the modernized German concept of breach of contract and types of non-performance. With regard to non-regulation of the uniform concept of breach and deficient regulation of particular types of breach (predominantly impossibility of performance, defective performance and breach of the duty of care) indicate that in the field of contract law the CCG has significantly deviated from the conceptual achievements of the fundamental reform of German law of obligations. Through episodic, inconsistent and non-systemic reception of the concept and types of breach of obligation, Georgian contract law moved away from the route of Europeanization. Grounds for this assertion are that the fundamental reform in Germany was essentially, conceptually influenced by EU directives and uniform legal instruments, like the CISG and the UPICC. From this perspective, reforming of German law of obligations according to conceptual tendencies of 'soft-law' codifications and implementation of requirements of EU directives (Löwisch, 2003, p. 141), may be acknowledged as a manifestation of the Europeanization of German law, in its essence.

Improvement of the normative framework of breach of contract and its particular types directly impacts the efficiency of the remedial system of contract law and implementation of private rights supposed to preserve performance interest, which in terms of legal protection, is a special merit of any legal system. "Private law remedies are simply the mirror reflection of primary rights [...] prospect of enforcing bilateral private rights is a perfectly acceptable means of protecting them" (Ripstein, 2009, cited in Barker \& Jensen, 2013, p. 36).

Contract law, the determinant of dynamism, flexibility and, at the same, the sustainability of civil turnover, the field, creating a necessary precondition for the formation of free trade area, should timely reflect the "impact of accelerated and fundamental changes" (Jugheli et al., 2014, p. 19) of Europeanization in order to serve the goal of unhindered implementation of internal and interstate legal and economic relations through a formation of flexible contractual infrastructure and legislative platform. 
On 1 July 2016, the EU-Georgia Association Agreement entered into force and Georgia's undertaking to approximate its legal framework with that of the EU in the field of private law necessitated comprehensive conceptualization of new realities for an efficient and enhanced administration of the EU integration process. The foregoing means promotion of the scrutiny of legal approximation with the EU institutions regulating civil-law relations and harmonization of private law at normative level, further improvement of legislative methodology that is based on the study of the EU law, research and sharing of international experience in the field of implementation of the institutions of EU law in domestic legislation, and harmonization with it.

In the context of legal approximation, the historical route of Europeanization should be renewed and consistently followed from the state perspective of EU associated country. For the mentioned purpose, harmonization with EU legislation and compliance with the most basic concepts of uniform contract law should also be supported by enhancement and improvement of EU law research methodology, sharing international experience with taking account of the national context and dichotomy of private law.

Dr. Tamar Zarandia is an associate professor and Dean at Ivane Javakhishvhili Tbilisi State University (TSU) Faculty of Law (Georgia), a member of the Institute of Contemporary Private Law at TSU, an expert of higher education and authorization of academic institutions in Georgia, a researcher at Max Planck Institute for Comparative and International Private Law through academic research scholarships in property and contract law.

Dr. Natia Chitashvili is an associate professor at the Ivane Javakhishvhili Tbilisi State University (TSU) Faculty of Law (Georgia), a member of the Institute of Contemporary Private Law at TSU, an executive director, certified trainer and mediator at TSU National Centre for Alternative Dispute Resolution, a member of mediators' roster for collective labor disputes at the Ministry of Internally Displaced Persons from the Occupied Territories, Labor, Health and Social Affairs of Georgia. Dr. Chitashvili's main fields of research are contract law, labor law and mediation. 


\section{References}

Association Agreement between the European Union and the European Atomic Energy Community and their Member States, of the one part and Georgia, of the other part, 27.06.14, date of publication 11.09.14, temporary application mode 01.09.14, date of full entry into force 01.04.16, OJ L261/4, 30.08.2014.

Barker, K. \& Jensen, D., eds. (2013), Private Law: Key Encounters with Public Law, New York: Cambridge University Press.

Basedow, J. (2005), 'Towards a universal doctrine of breach of contract: the impact of the CISG,' International Review of Law and Economics, vol. 25, pp. 487-500. https://doi.org/10.1016/j.irle.2006.02.009

Bassenge, P. et al., eds. (2019), Palandt Bürgerliches Gesetzbuch, 78. Auflage, München: Verlag C. H. Beck.

Principles of European Contract Law (2002), Parts I and II - Revised 1998, Part III, pp. xxi-xxii.

Berger, K. P. (2001), 'Principles of European Contract Law and the Concept of the Creeping Codification of Law,' European Review of Private Law, vol. 1, pp. 21-34.

Berger, K. P. (2010), The Creeping Codification of the New Lex Mercatoria, 2nd revised ed., Alphen aan den Rijn: Kluwer Law International.

Brunner, Ch. (2009), Force Majeure and Hardship under General Contract Principles: Exemption for Non-performance in International Arbitration, Alphen aan den Rijn: Kluwer Law International BV.

Bueno Diaz, O. (2008), Franchising in European Contract Law, Schriften zur Europäischer Rechtswissenschaft, vol. 8, Munich: Sellier. European Law Publishers.

Burduli, I. (2018), 'Nekrorezeption in Transformationsgesellschaftenin,' in M. Brinkmann, B. Völzmann-Stickelbrock \& D. O. Effer-Uhe (eds.) Dogmatik im Dienst von Gerechtigkeit, Rechtssicherheit und Rechtsentwicklung: Festschrift für Hanns Prütting, Cologne: Carl Heymanns Verlag, pp. 3-15.

Chachava, S. (2004), 'Retrieval of property from illegal possession,' [in Georgian] Georgian Law Review, vol. 4, no. 7, pp. 760-782.

Chanturia, L.; Zoidze, B.; Ninidze, T.; Shengelia, R. \& Khetsuriani, J., eds. (2001), Commentary on Georgian Civil Code, Book III: Law of Obligations, General Part, [in Georgian] Tbilisi: Publishing House "Samartali".

Chechelashvili, Z. (2006), Property Law, [in Georgian] Tbilisi.

Chen-Wishart, M.; Loke, A. \& Ong, B. (2016), Remedies for Breach of Contract, Studies in the Contract Law of Asia, Oxford: Oxford University Online. 
Chochia, A. (2013), Models of European Integration: Georgia's Economic and Political Transition, Dissertation Thesis, TUT Press.

Chochia, A. \& Popjanevski, J. (2016), 'Change of power and its influence on country's Europeanization process. Case study: Georgia,' in T. Kerikmäe \& A. Chochia (eds.) Political and Legal Perspectives of the EU Eastern Partnership Policy, Cham: Springer International Publishing Switzerland, pp. 197-208. https://doi.org/10.1007/978-3-319-27383-9_13

Ciematniece, I. (2010), Contract Renegotiation and Adaptation, Concept of Contract Renegotiation and Adaptation in International Commercial Law Contracts, Saarbrücken: Lambert Academic Publishing.

Decision of the Supreme Court of Georgia, No. 3K-624-02, 09.09.2002.

DiMatteo, L. A.; Zhou Q.; Saintier, S. \& Rowley, K. (2013), Commercial Contract Law, Cambridge: Cambridge University Press. https://doi.org/10.1017/CBO9781139235662

Dzneladze, N. (2007), 'Legal challenges of retrieval of property from illegal possession and property of property right,' [in Georgian] Martlmsajuleba [Justice], no. 2.

Friedmann, D. (1995), 'The performance interest in contract damages,' Law Quarterly Review, vol. 111, pp. 628-654.

Gegenava, D., ed. (2013), 'Preface,' [in Georgian] Collection of Articles Lado Chanturia 50: Anniversary Edition, Tbilisi: Davit Batonishvili Law Institute, p. 5.

German Civil Code (2005), Bürgerliches Gesetzbuch, Bundesministerium der Justiz, Saarbrücken: Juris GmbH.

Gesetz zur Modernisierung des Sculdrechts, Vom 26.11.2001, verkündet in Jahrgang 2001 Nr. 61 vom 29.11.2001.

Hesselink, M. (2010), Scope and Content of an Optional Instrument for EU Contract Law, Briefing Paper for the European Parliament Interparliamentary Committee Meeting on an Optional Instrument for EU Contract Law.

Joerges, C. (2005), 'Europeanization as process: thoughts on the Europeanization of private law,' European Public Law, vol. 11, no. 1, pp. 63-84.

Jugheli, G. et al., ed. (2014), Contract Law, [in Georgian] Tbilisi: Meridiani.

Keirse, A. L. M. (2011), 'European impact on contract law: a perspective on the interlinked contributions of legal scholars, legislators and courts to the Europeanization of contract law,' Utrecht Law Review, vol. 7, no. 1, pp. 39-42. https://doi.org/10.18352/ulr.145

Kreitner D. (2005), 'Multiplicity in contract remedies,' in N. Cohen \& E. McKendrick (eds.) Comparative Remedies for Breach of Contract, Portland, OR: Hart Publishing, pp. 19-50.

Kropholler, J. (2014), German Civil Code, Study Comments, [in Georgian] Tbilisi.

Kurzynsky-Singer, E. \& Zarandia, T. (2014), 'Rezeption des deutschen Sachenrechts in Georgien,' in E: Krzynsky-Singer (ed.) Transformation durch Rezeption?' 
Beiträge zum ausländischen und internationalen Privatrecht, vol. 102, Tübingen: Mohr Siebeck, pp. 107-138. https://doi.org/10.1628/978-3-16-153320-4

Lando, O. (1974), 'The EC draft convention on the law applicable to contractual and noncontractual obligations,' Rabels Zeitschrift für ausländisches und internationales Privatrecht, vol. 38, no. 1, pp. 6-55.

Lando, O. (2008), 'Optional or mandatory Europeanisation of contract law,' European Review of Private Law, vol. 8, no. 1, pp. 59-69.

Lando, O. \& Beale, H. (2000), Principles of European Contract Law, Part I, II, The Hague, London \& Boston: Kluwer Law International. https://doi.org/10.1007/97890-6704-575-9_24

Letto-Vanamo, P. \& J. Smits, J., eds. (2012), Coherence and Fragmentation in European Private Law, Munich: Sellier. European Law Publishers.

Löwisch, M. (2003), 'New law of obligations in Germany,' Ritsumeikan Law Review, no. 20, pp. 141-156.

Markesinis, S. B.; Unberath, H. \& Johnston, A. (2006), The German Law of Contract - A Comparative Treatise, 2nd ed., Oxford \& Portland, OR: Hart Publishing.

Mátyás, I. (2008), 'Current issues in the unification of European contract law,' European Integration Studies, Miskolc, vol. 6, no. 1, pp. 63-73.

Miller, L. (2011), The Emerge of EU Contract Law - Exploring Europeanization, Oxford: Oxford University Press. https://doi.org/10.1093/acprof:oso/9780199606627.003.0007

Paul, B. S. (1999), The Futility of Unification and Harmonization in International Commercial Law, University of Virginia School of Law, Legal Studies, Working Paper, no. 99-10.

Putkaradze, I. (2001), 'Gratuitous contracts in Georgian law,' [in Georgian] Georgian Law Review, no. 2, pp. 17-25.

Riesenfeld, S. (1993), 'The impact of German legal ideas and institutions on legal thought and institutions in the United States,' in M. Reimann (ed.) The Reception of Continental Ideas in the Common Law World 1820-1920, vol. 13, Berlin: Suncker \& Humbolt, Berlin, pp. 89-98.

Ripstein, A. (2009), Force and Freedom: Kant's Legal and Political Philosophy, Cambridge, MA: Harvard University Press.

Rosett, A. (1992), 'Unification, harmonization, restatement, codification, and reform in international commercial law,' American Journal of Comparative Law, vol. 40, no. 3, pp. 683-697. https://doi.org/10.2307/84059

Rowan, S. (2012), Remedies for Breach of Contract, a Comparative Analysis of the Protection of Performance, Oxford: Oxford University Press. https://doi.org/10.1093/acprof:oso/9780199606603.003.0001

Smits, J. (2012), 'Coherence and fragmentation in the law of contract,' in P. LettoVanamo \& J. Smits (eds.) Coherence and Fragmentation in European Private 
Law, Munich: Sellier. European Law Publishers, pp. 9-24.

Surguladze, Iv. (2002), Contract and Law, [in Georgian] translated from German and introduction by $\mathrm{O}$. Gamkrelidze, Tbilisi.

Zoidze, B. (2003), 'From the history of creation of Georgian civil code,' [in Georgian] Georgian Law Review, vol. 6/2003, no. 1.

Troitiño, D. R. \& Chochia A. (2011), 'Georgia and the European Union from the Mediterranean Perspective,' Baltic Journal of European Studies, vol. 2, no. 1(11), pp. 81-102.

Twigg-Flesner, C. (2013), The Europeanisation of Contract Law: Current Controversies in Law, 2nd ed., London \& New York: Routledge, Taylor \& Francis Group. https://doi.org/10.4324/9780203549377

UN (2010), United Nations Convention on Contracts for the International Sale of Goods (CISG) 1980, United Nations Commission on International Trade Law, New York: United Nations.

UNIDROIT (2014), UNIDROIT Principles of International Commercial Contracts (UNIDROIT Contract Principles or UPICC), Rome: International Institute for the Unification of Private Law.

van Erp, S. (2012), 'European property law: a new and rapidly developing area of research and teaching,' European Property Law Journal, vol. 1, no. 1, pp. 1-2. https://doi.org/10.1515/eplj-2012-0001

von Bar, C. et al., eds. (2009), Principles, Definitions and Model Rules of European Private Law, Draft Common Frame of Reference (DCFR), Study Group on a European Civil Code and Research Group on EC Private Law (Acquis Group), Munich: Sellier. European Law Publishers GmbH.

Wagner, G. (2002), 'The economics of harmonization: the case of contract law,' Common Market Law Review, vol. 39, no. 5, pp. 995-1023. https://doi. org/10.1023/A:1020884210205

Westermann, P. (2012), BGB - Sachenrecht, 12. Auflage, Heidelberg: C. F. Müller.

Williston, S. \& Lord, R. A. (1990), A Treatise on the Law of Contracts, 4th ed., Eagan, MN: West Group.

Wolf, M. \& Wellenhofer, M. (2016), Sachenrecht, 31. Auflage, Köln: C. H. Beck.

Zarandia, T. (2007), 'The national character of private law and the necessity of reception,' [in Georgian] Guram Tavartkiladze Anniversary Collection, Tbilisi: TSUER, pp. 294-304.

Zeller, B. (2007), CISG and Unification of International Trade Law, Abingdon \& New York: Routledge-Cavendish. https://doi.org/10.4324/9780203932889

Zoidze, B. (2005), Reception of European Private Law in Georgia, [in Georgian] Tbilisi: Tinatin Tsereteli Institute of State and Law of the Academy of Science of Georgia. 